\title{
Norwegian Arctic Expansionism, Victoria Island (Russia) and the Bratvaag Expedition
}

\author{
IAN GJERTZ ${ }^{1}$ and BERIT MØRKVED ${ }^{2}$
}

\author{
(Received 6 October 1997; accepted in revised form 22 March 1998)
}

\begin{abstract}
Victoria Island (Ostrov Viktoriya in Russian) is the westernmost island of the Russian Arctic. The legal status of this island and neighbouring Franz Josef Land was unclear in 1929 and 1930. At that time Norwegian interests attempted, through a secret campaign, to annex Victoria Island and gain a foothold on parts of Franz Josef Land. We describe the events leading up to the Norwegian annexation, which was later abandoned for political reasons.
\end{abstract}

Key words: Franz Josef Land, Victoria Island, Norwegian claim, acquisition of sovereignty

RÉSUMÉ. L'île Victoria (en russe Ostrov Viktoriya) est l'île la plus occidentale de l'Arctique russe. En 1929 et 1930, le statut légal de cette île et de l'archipel François-Joseph voisin n'était pas bien défini. À cette époque, les intérêts norvégiens tentaient, par le biais d'une campagne secrète, d'annexer l'île Victoria et d'établir une emprise sur des zones de l'archipel François-

Joseph. On décrit les événements menant à l'annexion norvégienne, annexion qui fut délaissée par la suite pour des raisons politiques.

Mots clés: archipel François-Joseph, île Victoria, revendication norvégienne, acquisition de la souveraineté

Traduit pour la revue Arctic par Nésida Loyer.

\section{INTRODUCTION}

Norway has a long tradition in Arctic exploration, fishing, sealing, and hunting. Most Norwegian activity occurred during the latter half of the 19th century and was usually undertaken on a private or commercial basis. From the beginning of the 20th century, Arctic exploration entered a nationalistic phase (Skagestad, 1975), and from 1909 on Svalbard was visited regularly by Norwegian scientific expeditions financed by the Norwegian government and various Norwegian institutions, as well as by private individuals. These scientific expeditions were called De Norske Statsunderst $\varnothing$ ttede Spitsbergenunders $\varnothing$ kelser (Norwegian State-aided Spitsbergen Expeditions) (Greve, 1975). In 1928, Parliament established Norges Svalbard- og IshavsUnders $\varnothing$ kelser or NSIU (Norway's Svalbard and Arctic Ocean Research Survey). In 1948, this body was renamed Norsk Polarinstitutt (Norwegian Polar Institute).

After World War I, Norwegian interests, especially whaling and sealing interests, were active in expanding Norwegian territory in the polar areas (Isachsen, 1929). Svalbard became Norwegian in 1925, and Jan Mayen followed in 1929 (Skagestad, 1975; Barr, 1987). Norway claimed East Greenland in 1931, but lost that territory to Denmark in a 1933 verdict of the International Court in the Hague (Brøgger, 1933; Skagestad, 1975). In the Antarctic, Bouvet Island became Norwegian in 1928, Peter I Island in 1933, and Queen Maud Land in 1939 (Skagestad, 1975; Barr, 1987).
One of the bases for claiming these polar areas was that Norwegians either had discovered them or had vital economic interests in them as the most important commercial users of the areas (Horn, 1930a; Hoel, 1931; Smedal, 1931; Skagestad, 1975).

\section{FRANZ JOSEF LAND AND VICTORIA ISLAND}

Franz Josef Land is officially recognized as having been discovered in 1873 by the Austro-Hungarian Tegetthoff expedition (Payer, 1876). Norwegian sources had claimed that the islands were first discovered in 1865 by the Norwegian sealers Rønnbeck and Aidijärvi aboard the schooner Spidsbergen (Horn, 1930a); however, this claim is disputed (Dörflinger, 1976). Although Franz Josef Land was difficult to access because of severe ice conditions, regular expeditions to the islands started during the last decade of the 19th century, partly because of the introduction of larger, steam-powered vessels. Horn (1930a) listed all known expeditions to Franz Josef Land showing that at least $80 \%$ of these were Norwegian in origin. This fact indicates the importance of Franz Josef Land to Norwegian interests.

Victoria Island (Ostrov Viktoriya), is a small Russian island situated at $80^{\circ} 10^{\prime} \mathrm{N} 37^{\circ} \mathrm{E}$ between the Norwegian Arctic archipelago Svalbard and the Russian archipelago Franz Josef Land (Fig. 1). This westernmost of all the Russian Arctic islands, about $40 \mathrm{~km}^{2}$ and almost completely

\footnotetext{
${ }^{1}$ Norwegian Polar Institute, N-9005 Troms $\varnothing$, Norway; gjertz@ npolar.no

${ }^{2}$ ARC - Arctic Research and Consulting, Arilds Vei 18, 0491 Oslo, Norway

(C) The Arctic Institute of North America
} 


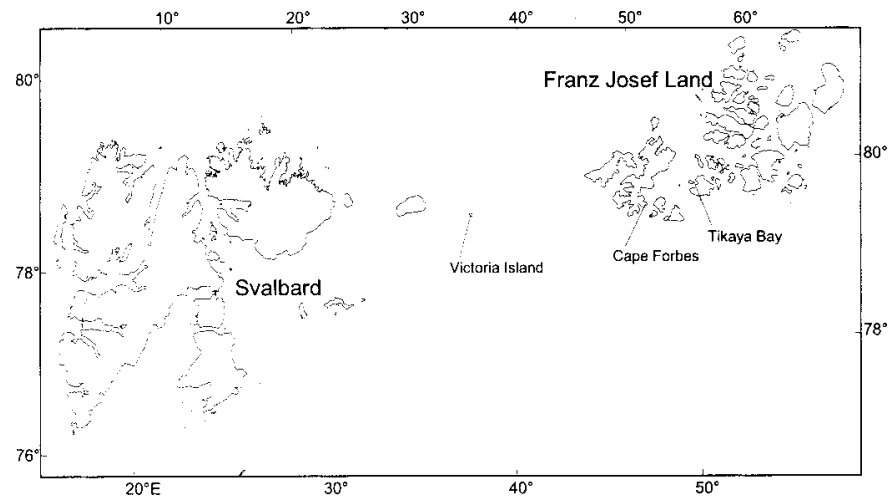

FIG. 1. Map indicating the position of Victoria Island, between Svalbard and Franz Josef Land.

ice covered, is administered as part of Franz Josef Land. The island was discovered a century ago, on 20 July 1898 , by two Norwegian sealing captains, Johannes Nilsen and Ludvig Bernhard Sebulonsen (Isachsen, 1919). The next day Captain P.W. Nilssen of the Norwegian steam yacht Victoria, which belonged to the English adventurer Arnold Pike, sighted the island and named it after the yacht (Isachsen, 1919). The island was considered a no-man'sland until it was claimed by the Soviet Union on 15 April 1926 as lying within the Soviet sector (Breitfuss, 1928; Smedal, 1931). The Soviet flag was first raised on Victoria Island on 29 August 1932; it was placed on the northwesternmost point of the island by Captain S.V. Popoff from the expedition ship N. Knipovitsj (Anon., 1933a).

\section{NORWEGIAN INTERESTS}

The Soviet decree of 15 April 1926 that claimed a Soviet sector in the North Polar region also included Franz Josef Land and Victoria Island in the territory claimed. The Soviet Union notified Norway of its claim on 6 May 1926, and on 19 December 1928 Norway officially protested (Skagestad, 1975). Smedal (1931) listed several Soviet flag hoistings on Franz Josef Land, but contested the legality of the Soviet sector claim. He concluded that since foreign powers had not been notified of the Soviet flag hoistings, they had no legal importance, and that the Soviet Union had not taken effective possession of the archipelago, but only of a couple of the islands.

The Soviet claim to Franz Josef Land and Victoria Island was a cause of concern both to Norwegian authorities such as NSIU and to interests connected with the sealing fleet. This concern led to a secret campaign, headed by Adolf Hoel, the director of NSIU, to claim possession of Victoria Island for Norway (Hoel, 1977).

On 18 April 1929, Hoel cabled Carl S. Sæther requesting information about vessels that had been to Victoria Island (NP Library reference SM4479). Sæther was a wellknown owner of a Troms $\varnothing$-based sealing fleet, and also British vice-consul in Troms $\emptyset$. On 30 April, Sæther sent
Hoel a four-page letter containing the results of interviews he had conducted with sealing captains about Victoria Island (NP Library reference SM4479). Armed with this information, Hoel met on 6 May with Thor Iversen of the Fisheries Directorate and Assistant Secretary Talnum of the Ministry of Commerce to plan an annexation of Victoria Island using the Fisheries Directorate expedition vessel. They agreed that to do this the expedition budget would have to be increased from 30000 to 35000 Norwegian kroner, and that the expedition therefore had to apply for more funds (Ministry of Foreign Affairs archives J. no. 07557 UD/1929 dated 10 May). On 23 May, the Ministry of Commerce accepted the suggested increase, but pointed out that no formal decision had yet been taken on the annexation of Victoria Island, and that this should only be done when the order was given (Ministry of Foreign Affairs archives J. no. 07557 UD/1929 dated 23 May). On the basis of this information Hoel sent a six-page report on Victoria Island to the Norwegian Ministry of Foreign Affairs (NP Library reference SM4479) on 5 June. The Foreign Ministry in turn contacted the Ministry of Commerce on 14 June regarding Victoria Island (NP Library reference SM4479). The Ministry of Foreign Affairs did not wish to take any measures to lay official claim to the island, but had no objection to a private Norwegian claim. Officials emphasized that such a claim should be made by a person who was not employed by the government, and preferably by an individual who would benefit professionally by such a claim, for example, the skipper of the Fisheries Directorate's expedition vessel to the area. The Ministry further suggested that the claim should be made by erecting one or more annexation signs stating when and by whom the island was claimed and also the names of the witnesses. Neither of the witnesses should be government employees. A small cabin should be erected and a written statement regarding the occupation stored therein. Expenses connected to the occupation could be covered by the Fisheries Directorate expedition.

On 12 July, the Ministry of Commerce contacted the Director for Fisheries (Head of the Fisheries Directorate) authorizing him to take steps to carry out the Ministry of Foreign Affairs' plan for Victoria Island (NP Library reference SM4479). They further emphasized that before the private individual claimed the island, he should sign a confidential agreement that he would transfer his claim to the Norwegian state.

On 7 August, Adolf Hoel at NSIU sent a cable to Thor Iversen, leader of the Fisheries Directorate expedition vessel M/C His $\phi$ lying in Troms $\emptyset$. The cable instructed Iversen to occupy Victoria Island according to the Foreign Ministry instruction of 14 June. The crew was furthermore to erect a hut and leave provisions and equipment in it. The claim signs and hut were to be photographed. Possibly there was already a cabin on the island. If so, the party was to photograph and measure it and attempt to find out who had built it. Iversen was also informed that the expedition of consul Lars Christensen (the famous whaling tycoon 


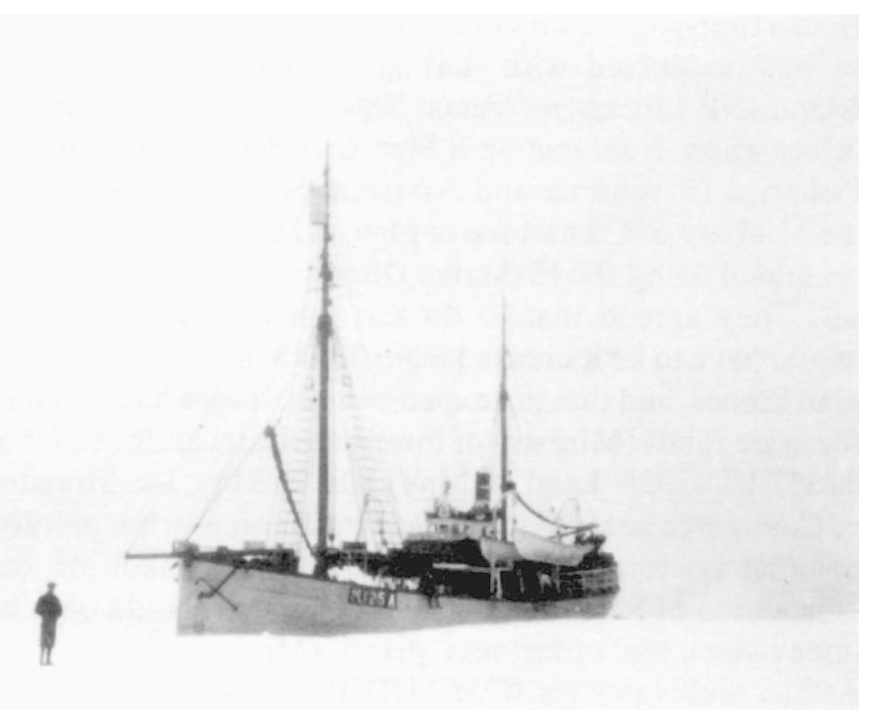

FIG. 2. M/S Bratvaag in the pack ice near Franz Josef Land, August 1930. Photo by G. Horn, Norwegian Polar Institute collection.

whose expeditions in Antarctica annexed Bouvet Island and Peter I Island), consisting of the vessels S/S Tornes and M/C Hvalrossen, had just left Troms $\emptyset$. Gunnar Horn, a NSIU geologist, was aboard the M/C Hvalrossen. Ice permitting, that expedition would claim the island. If Iversen were to find their claims on the island, he was not to take any action (NP Library reference SM4479).

The Christensen expedition's main goal was to erect a meteorological station, with a wireless radio, and leave a five-man wintering crew on Franz Josef Land (Horn, 1930a). However, the expedition never reached Franz Josef Land because of severe ice conditions. Thor Iversen's His $\phi$ expedition suffered the same fate. Neither expedition had icebreakers at its disposal. The purpose of establishing a manned radio station in Franz Josef Land was undoubtedly to obtain a legal footing in part of the archipelago before the Soviets did so (see Smedal, 1931 for details on acquiring possession of polar areas; Barr, 1995). However, the Soviet Union managed to get to Franz Josef Land using the icebreaker Georgij Sedov, and on 29 July 1929 Professor Schmidt of the Sedov expedition raised the Soviet flag at Tikaya Bay, Hooker Island, and declared that Franz Josef Land was a part of the Soviet Union (Smedal, 1931).

\section{THE BRATVAAG EXPEDITION}

Despite the setbacks in 1929, the Norwegians made a new attempt the following year. This time ice conditions were favourable (Horn, 1930b), and the NSIU expedition ship M/S Bratvaag (Fig. 2) arrived at Victoria Island on 8 August 1930. At 0430, seven people went ashore: expedition leader Gunnar Horn, ship's captain Peder Eliassen, botanist Olaf Hanssen, zoologist Adolf Sørensen, Bjarne Ekornaasvaag, and the two trappers Lars Tusvik and Syver
Alvestad. They landed on the only beach on the island, about $800 \mathrm{~m}^{2}$ in area, situated on the northwestern side, the only place where it was possible to get ashore (Ministry of Foreign Affairs archives J. no. 19470 U.D/1930). The beach was snow-covered and no sign of any other claim to the island was seen, despite rumour in Troms $\varnothing$ that a competing vessel, M/S Isbjørn, was planning to sail to the island and occupy it for another private owner (Horn, 1930c). Horn therefore decided to claim the island, and ordered the building materials sent ashore (Horn, 1930c). In the meantime Horn, Eliassen, and Hanssen climbed to the top of the island (Horn, 1930c; Hanssen, 1933). Later, they raised a claim sign on the beach (Fig. 3). It read: Victoria Island claimed for Harald M. Leite [the ship's owner], Ålesund, Norway. P. Eliassen, Skipper of $M / S$ Bratvaag, 8. August 1930. L. Tusvik, S. Alvestad. In a bottle placed between the stones at the foot of the claim sign, a note written in Norwegian was placed. It read: "I have today claimed Victoria Island for Harald M. Leite, Aalesund, Norway. The claim includes the whole of the island." The note, dated 8 August 1930, was signed by the same people whose names appeared on the sign. Next to the claim sign, building materials, nails, and a hammer were placed. They were sufficient to build a $2 \times 3 \mathrm{~m}$ cabin. But as it was not possible to secure the cabin against a storm, it was not erected. The landing party left the island and at 0755 the Bratvaag sailed for Franz Josef Land. There they conducted scientific investigations and hunted, but they also built a cabin at Cape Forbes, George Land, in which they left provisions (Fig. 4) (Horn, 1931). The cabin was supposedly intended as a refuge for scientists or hunters working in this area. The Bratvaag arrived back in Tromsø, Norway on 2 September 1930.

\section{EPILOGUE}

The true purpose of the Bratvaag expedition was kept secret. Horn (1931) states that the building material was left on Victoria Island for the use of shipwrecked crews who might reach the island. Had it not been for another event, the Bratvaag expedition would be long forgotten. However, on 6 August 1930, two days before Victoria Island was claimed, the crew found the long-lost remains of the Swedish explorer Andrée's balloon expedition to the North Pole, which had vanished in 1897. This find would become a world sensation!

Today it may seem somewhat strange that the annexation of Victoria Island was kept such a secret. Messrs Hoel and Horn were usually very outspoken about Norwegian interests in the Arctic and their personal involvement in such matters. Even though it is not stated in the archive material, it seems that fear of upsetting the Soviet Union lay behind this secrecy, and that strong forces in the Foreign Ministry wished to keep the secret. Two years later, in September 1932, it became known that the Soviet Union had annexed Victoria Island. This revelation led to 


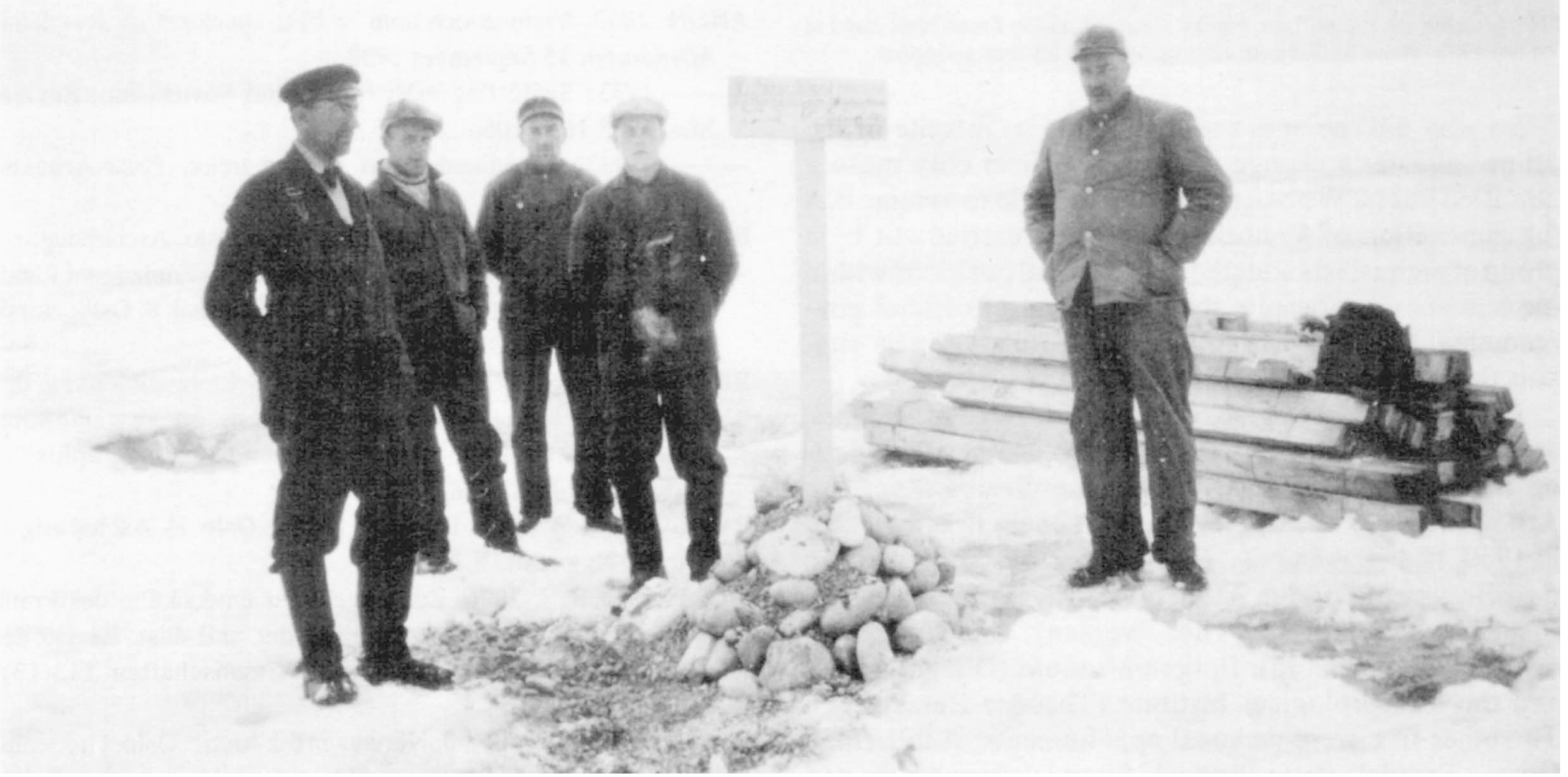

FIG. 3. Building materials and annexation claim sign on Victoria Island, 8 August 1930. The people in the picture from left to right are Peder Eliassen, skipper M/S Bratvaag; Syver Alvestad; Bjarne Ekornaasvaag; Lars Tusvik; and Olaf Hanssen. Photo by G. Horn, Norwegian Polar Institute collection.

some discussion in Norwegian newspapers concerning Arctic policy, and on 15 September 1932, Aftenposten, Norway's leading newspaper, published an article about Leite's private annexation. This article contained a photograph similar to Figure 3 (Anon., 1932).

One question that arises is why the Norwegian Government explicitly supported the annexation in 1929, when it knew that such a step would raise difficulties with the Soviets, and then later abandoned this view after their 1930 annexation. According to Assistant Secretary Fredrik Marstrander in the Ministry of Foreign Affairs, there were several reasons (Ministry of Foreign Affairs archive J. no. 10385 U.D./1931 dated 16 July 1931). The annexation was seen as an effective protest against the Soviet decree of 15 April 1926 claiming a sector to the North Pole. Furthermore, it could be used later to negotiate compensation for possible loss of Norwegian interests in Franz Josef Land. Marstrander claims that Johan Ludwig Mowinckel, the prime minister and foreign minister at that time, intended to make a formal decision on the annexation in a meeting of government in 1929. When the Norwegian Parliament cancelled the budget proposed for the planned governmental expedition to Franz Josef Land, he decided to drop the annexation plans. Mowinckel had also expressed fear that an annexation might lead the Soviet Union to withdraw from the bilateral trade agreement with Norway signed in 1925 (Skagestad, 1975), which gave Norwegian sealers access to the sealing grounds in the White Sea. If this were to happen, it might lead to a substantial financial loss. Instead, the Norwegian government sent a note to the Soviet Union regarding the Norwegian commercial hunting interests on and among these islands (Hoel, 1977; Barr, 1995). They hoped that the Soviet Union would allow hunting to continue, but the Soviet Union established a 12 nautical mile exclusion zone, i.e., territorial limit, around the islands and denied access to all foreign vessels. Visits did occur after this (Barr, 1995), and some illegal hunting continued: the last known incident took place in 1953 (Lønø, 1972). 


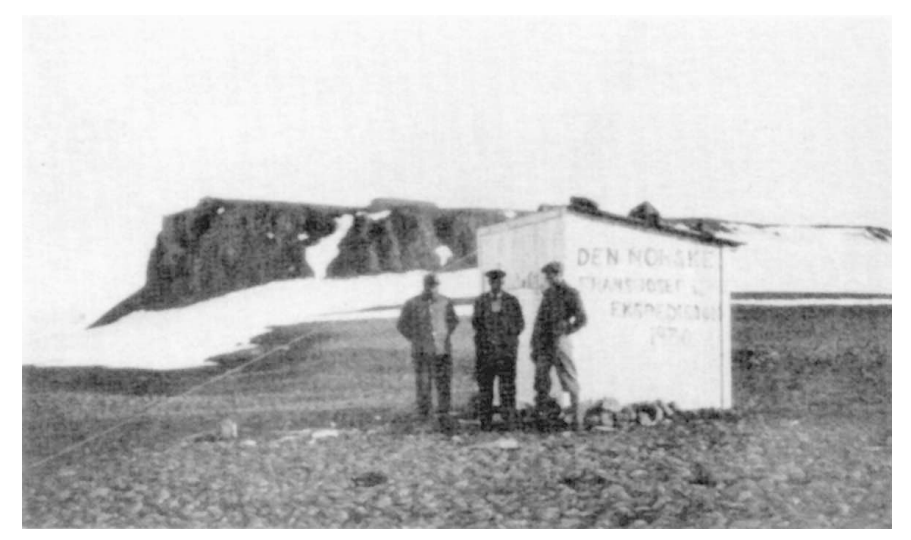

FIG. 4. Cabin erected at Cape Forbes, George Land in Franz Josef Land in August 1930. Photo by G. Horn, Norwegian Polar Institute collection.

So why did the annexation take place, in spite of the prime minister's change of heart? We can only make a qualified guess. We believe it is reasonable to assume that the annexation of Victoria Island was carried out by a group of enthusiasts situated in influential positions within the bureaucracy, despite the withdrawal of official governmental support. The following information may support this view.

In 1928, the Norwegian Parliament decided to establish an expert committee on Arctic affairs, Norges Svalbardog Ishavsråd (Norwegian Council for Svalbard and the Arctic Seas) (Skagestad, 1975). This council, established in 1930, had 10 members. Half were representatives from the Ministry of Foreign Affairs (Fredrik Marstrander), the Fisheries Directorate (Thor Iversen), the University (Werner Werenskiold), Bergen Museum (Ole Krogness) and the Meteorological Institute (Theodor Hesselberg). The other five were personal appointments: Adolf Hoel, Gustav Smedal, Peter Brandal, Sigurd Johannessen, and Anton Jacobsen. Hoel and Smedal were close friends, and both had interests in gaining new land for Norway (Hoel 1931, 1977; Smedal, 1931). Brandal was a capitalist who had claimed and built up the coal-mining town $\mathrm{Ny}$-Ålesund in Svalbard, while Svalbard was still a no-man's-land. Johannessen was commercial attaché with the Ministry of Commerce, and Anton Jacobsen was director of a Troms $\varnothing$ bank and a keen spokesman for whaling and sealing interests. Assistant Secretary Fredrik Marstrander was adviser to the Ministry of Foreign Affairs in matters dealing with the Arctic. Krogness had established a number of weather stations in the Arctic, in Svalbard, Jan Mayen, and Greenland. Fisheries Directorate representative Thor Iversen was involved in the annexation plans for Victoria Island from the start, and finally the Meteorological Institute had privately annexed the island of Jan Mayen in 1922. Needless to say this council must have been somewhat biased, and even though their first meeting was held in 1931, it is reasonable to assume that many of the council members had shown engagement prior to this. Otherwise, it is doubtful that they would have been appointed members of the council. Many of the above-mentioned council members were personally involved, or represented branches of government that were involved, in the first plans for the annexation of Victoria Island. The council's attitude, and also its members' attitudes, may be better understood when seen in context with another polar expansion. The same council stood behind the Norwegian annexation of East Greenland in 1931. That annexation resulted in a political scandal (Skeie, 1933; Anon. 1933b) and led Parliament to dissolve the council in 1933 (Skagestad, 1975)!

\section{REFERENCES}

ANON. 1932. Victoria-øen som er blitt annektert av Russland. Aftenposten 15 September 1932.

. 1933a. Soviet flag on Victoria Island. Soviet Union Review May 1933:105-106.

. 1933b. Grønlandssaken i korte trekk. Polar-Årboken 1933:157.

BARR, S. 1987. Norway's polar territories. Oslo: Aschehoug. 1995. The history of western activity in Franz Josef Land.

In: Barr, S., ed. Franz Josef Land. Polarhåndbok 8. Oslo: Norsk Polarinstitutt. 59-106.

BREITFUSS, L. 1928. Die territoriale Sektoreneinteilung der Arktis im Zusammenhang mit dem zu erwartenden transarktischen Luftverkehr. Petermanns Geographische Mitteilingen 74:23-28.

BRØGGER, A.W. 1933. Dommen i Haag. Oslo: H. Aschehoug \& Co. (W. Nygaard).

DÖRFLINGER, J. 1976. Zur frage einer entdeckung des Franz Josefs-Landes vor 1873. Anzeiger der phil.-hist. Klasse der Österreichischen Akademie der Wissenschaften 113(13): 363-371.

GREVE, T. 1975. Svalbard: Norway in the Arctic. Oslo: Grøndahl. HANSSEN, O. 1933. Dei fyrste på toppen av Victoria- $\varnothing$ yi. PolarÅrboken 1933:131 - 133.

HOEL, A. 1931. Trues våre arktiske interesser? Samtiden 42: $233-246$.

. 1977. Mitt liv i og for polartraktene. Oslo: John Griegs Forlag.

HORN, G. 1930a. Franz Josef Land: Natural history, discovery, exploration, and hunting. Skrifter om Svalbard og Ishavet 29:1-54. - 1930b. "Bratvaag" ekspedisjonen finner leiren. In: Svenska Sällskapet för Antropologi och Geografi, eds. Med Ørnen mot polen. Oslo: Gyldendal Norsk Forlag. 160-179.

— 1930c. Private diary. Held at Norsk Polarinstitutt Library. Middelthunsgate 29, N-0301 Majorstuen, Oslo.

_ 1931. Ekspedisjonen til Franz Josefs Land. Norsk Geografisk Tidsskrift 3:396-405.

ISACHSEN, G. 1919. Fra ishavet. Ishavsfarer Sivert Tobiesen. Folk, fangst og færder. Norske Geografiske Selskabs Aarbok 1916-1919.

- 1929. Modern Norwegian whaling in the Antarctic. Geographical Review 19(3):387-403.

LØNØ, O. 1972. The catch of walrus (Odobenus rosmarus) in the areas of Svalbard, Novaja Zemlja, and Franz Josef Land. Norsk Polarinstitutt Årbok 1970:199-212. 
MINISTRY OF FOREIGN AFFAIRS ARCHIVES. Utenriksdepartementet. Arkivkontoret. P.B. 8114 Dep., N-0032 Oslo, Norway.

NP LIBRARY (NORWEGIAN POLAR INSTITUTE LIBRARY). P.O. Box 399, N-9005 Troms $\varnothing$, Norway.

PAYER J. 1876. New lands within the Arctic Circle. London: Macmillan and Co.
SKAGESTAD, O.G. 1975. Norwegian polar politics and policies. Main features and trends 1905-1974. (In Norwegian with English summary). Oslo: Dreyers Forlag.

SKEIE, J. 1933. Politikere og diplomater i Grønlandssaken. Oslo: Olaf Norlis Forlag.

SMEDAL, G. 1931. Acquisition of sovereignty over polar areas. Skrifter om Svalbard og Ishavet 36:1-143. 